\title{
Brazilian cheese bread rolls from fermented and native waxy maize starch
}

\section{Pão de queijo a partir de amido de milho ceroso nativo e fermentado}

\author{
Camila Souza Teixeira' ${ }^{(\mathbb{D})}$, Glenda Antonia da Rocha Neves ${ }^{1 *}(\mathbb{D})$, Tatianne Ferreira de Oliveira1 (iD), \\ Márcio Caliari' ${ }^{1 D}$, Manoel Soares Soares Júnior ${ }^{1}$ (ID
}

'Universidade Federal de Goiás/UFG, Escola de Agronomia e Engenharia de Alimentos, Goiânia, GO, Brasil

*Corresponding author: neves.gar@gmail.com

Received in March 13, 2020 and approved July 17, 2020

\begin{abstract}
Brazilian cheese bread (CB) rolls are gluten-free bread made from sour cassava starch. They are soft in the center and have crispy crust, reminding of the extruded structure. Although native waxy maize starch (WMS) has higher technologic quality, it has not been used in CB rolls; therefore, this study aimed to investigate the use of WMS and the backslopping fermentation process plus sun drying in WMS to replace sour cassava starch $(0,25 \%, 75 \%$, and $100 \%)$ and the effects on dough development, color, and textural properties. Data were analyzed using variance and Tukey test $(p \leq 0.05 \%)$, and the results were set against a commercial product from cassava starch. The better formulation was characterized by proximal composition, sensorial acceptance, and willingness to buy, and data were presented as means and standard deviation. The different statistic parameters included color to redness coordinate, baking expansion capacity, specific volume, hardness, fracturability, and chewiness. The best formulation had $100 \%$ of sundried WMS and was microbiologically safe. The proximal composition had lower values than that obtained from the Brazilian Food Database. The product was considered satisfactory as it had a score of more than 7.79 to texture, appearance, and flavor with higher willingness to buy (92.5\%). The backslopping fermentation plus SWMS was considered a potential replacement for sour cassava starch.
\end{abstract}

Index terms: Gluten-free bread; backslopping fermentation; starch modification; bakery; celiac diet.

\begin{abstract}
RESUMO
Pão de queijo (PQ) é um produto sem glúten, produzido a partir de amido de mandioca azedo. Apresenta casca crocante e miolo macio, lembrando uma estrutura extrudada. O amido de milho ceroso (AMC) é conhecido pela sua qualidade tecnológica e não foram encontrados estudos para sua aplicação na produção de PQ. Neste sentido o presente trabalho objetivou investigar o uso de AMC e de AMC fermentado, utilizando polvilho azedo de mandioca como inóculo, e seco ao sol (AMCF) na substituição do amido convencional (0, 25,75, e $100 \%$ e seus efeitos no desenvolvimento da massa, cor e propriedades de textura. Os dados foram analisados por ANOVA e teste de Tukey $(\mathrm{p} \leq 0.05 \%)$ e os resultados foram comparados com um produto comercial A melhor formulação foi caracterizada quanto sua composição proximal, aceitação sensorial e pela intenção de compra e os dados são apresentados pelas suas médias e desvio-padrão. Os parâmetros que diferiram estatisticamente foram as coordenadas de cor para o vermelho, capacidade de expansão, volume específico. Com $100 \%$ de AMCF a melhor formulação foi microbiologicamente segura. A composição proximal apresentou valores menores quando comparados com os valores da Tabela Brasileira de Composição de Alimentos. O produto pode ser considerado com boa aceitação, já que apresentou notas maiores que 7,79 para textura, aparência, sabor e intenção de compra. O AMCF pode ser considerado como um bom substituto para o polvilho azedo de mandioca.
\end{abstract}

Termos para indexação: Gluten-free; fermentação; amido modificado; panificação; dieta celíaca.

\section{INTRODUCTION}

Brazilian cheese bread $(\mathrm{CB})$ rolls are a bakery product with a crispy crust and soft center. They taste savory and sweet (Chadbourn, 2016). As CB rolls are a higher source of energy and do not contain gluten, it is widely consumed in Brazil (INMETRO, 2017). This kind of bread has rarely been studied. It is a mixture of low moisture cheese, eggs, milk, fat, salt, and cassava starch, which can be native, sour, or a mixture of both (Anjos et al., 2014; Fernandes et al., 2015; Papalia et al., 2015).

The process of obtaining sour cassava starch turns the native starch into a product with a high expansion characteristic, and during baking, it behaves like extruded snacks (alveolar structure, high specific volume, and crispness). Fermentation and sun drying (SD) processes are used to obtain sour cassava starch. Because of 
fermentation, starch has a low viscosity peak and higher paste clarity and solubility (Demiate; Kotovicz, 2011). Moreover, SD affects the pasting properties of starch through oxidation (ultraviolet [UV] radiation) (Santos; Sartori; Cabello, 2012).

Although changes are observed in maize starch after UV oxidation, they are not adequate to change maize starch to sour cassava (Bertolini et al., 2001). On the other hand, waxy starch retains more water, can be easily solubilized, has a compact physical structure, and changes its structure after swelling (Schirmer et al., 2013). Therefore, it can be easily modified as shown in our previous study (Teixeira et al., 2019); however, it has not been used in CB rolls. Cassava is not available in some temperate regions such as the USA and Europe, and its production is lower than maize (Faostat, 2017). Therefore, this study aimed to produce CB rolls using different proportions of native waxy maize starch (WMS) and sour waxy maize starch (SWMS) by SD after backslopping fermentation to replace sour cassava starch and compare characteristics from them to a commercial product from cassava starch.

\section{MATERIAL AND METHODS}

\section{Raw materials}

Raw eggs, meia cura cheese (São Francisco, Brazil), soy oil (Sinhá, Brazil), sodium chloride (Cisne, Brazil), and cassava sour starch (Kodilar, Brazil) were purchased from a local market in Goiania (city of State of Goias, Brazil). WMS was obtained from Fecularia Bela Vista (Bela Vista de Goiás, Goiás, Brazil).
Sour waxy maize starch by backslopping fermentation and sun drying

In our previous study (Teixeira et al., 2019) the WMS $(5 \mathrm{~kg}$ ) was fermented using the commercial sour cassava starch $(375 \mathrm{~g})$ as inoculum at $25^{\circ} \mathrm{C}$ in the plastic containers with $8 \mathrm{~L}$ of water for 11 days until $4 \%$ of total acidity was achieved. The water was drained and fermented WMS was poured in aluminum trays and sun

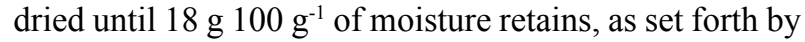
the Brazilian legislation in force (Brazil, 1978).

\section{Brazilian cheese bread rolls processing}

The main formulation of $\mathrm{CB}$ rolls used was $250 \mathrm{~g}$ of starch, $135.6 \mathrm{~g}$ of water, $41.1 \mathrm{~g}$ of oil, 5.5 $\mathrm{g}$ of salt, two eggs, and $62.5 \mathrm{~g}$ of grated cheese and was adapted from the Machado and Pereira's study (2010). Other formulations were obtained from this study, and a completely randomized design was used (Table 1), with five treatments (replacement levels of SWMS by WMS: $0,25 \%, 50 \%, 75 \%$, and $100 \%$ ) and four repetitions.

For dough development, the ingredients were manually mixed as follows: scalding SWMS, native WMS, or a mixture of both were taken with boiling water and oil and after cooling at $25^{\circ} \mathrm{C}$, raw eggs, salt, and cheese were added and mixed until a homogeneous dough was formed. Then, rolls of approximately $15 \mathrm{~g}$ were manually made. $\mathrm{CB}$ rolls were ready after $20 \mathrm{~min}$ of baking at $180^{\circ} \mathrm{C}$ in a preheated electric oven (electric oven - FERI60, Venâncio Aires, Brazil); they were then cooled and packed in low-density polyethylene bags for physicochemical analyses.

Table 1: Replacement levels of WMS by SWMS in Brazilian cheese bread rolls (CB) formulations.

\begin{tabular}{cccccc}
\hline \multicolumn{5}{c}{ Replacement levels of WMS by SWMS } \\
\hline Ingredient $^{1}$ & 100 (CB1) & 75 (CB2) & 50 (CB3) & 25 (CB4) & 0 (CB5) \\
\hline SWMS & 250 & 187.5 & 125 & 62.5 & 0 \\
WMS & 0 & 62.5 & 125 & 187.5 & 250 \\
Soy oil & 41.1 & 41.1 & 41.1 & 41.1 & 41.1 \\
Water & 135.6 & 135.6 & 135.6 & 135.6 & 135.6 \\
Cheese & 62.5 & 62.5 & 62.5 & 62.5 & 62.5 \\
Salt & 5.5 & 5.5 & 5.5 & 5.5 & 5.5 \\
Raw eggs & 112 & 112 & 112 & 112 & 112 \\
\hline ' $\mathrm{g}$; CB1: 100/0; CB2: 75/25; CB3: 50/50; CB4: 25/75; CB5: 0/100 percentage of replacement of SWMS (sour waxy maize starch) \\
and WMS (native waxy maize starch).
\end{tabular}




\section{Physical analyses}

The expansion index was determined using the ratio of the unit diameter plus unit height divided by two before and after baking. A digital pachymeter (Digital Messen, Messen, Berlin, Germany) was used to measure the diameter and height $(\mathrm{mm})$ of bread before and after baking. The bread volume was measured using the displacement of millet seeds method and weighed using a precision balance, accurate up to two decimal points. The specific volume was calculated using the volume/weight ratio (Machado; Pereira, 2010). The color parameters were measured using a colorimeter (CR-10, Konica Minolta, Ramsey, EUA) in the CIELab scale, from which the chroma $\left(\mathrm{C}^{*}\right)$ and hue angle $\left(\mathrm{H}^{\circ}\right)$ were calculated. Each $\mathrm{CB}$ roll was considered one repetition and was read as six-fold to each CB.

After baking for $30 \mathrm{~min}, 10 \mathrm{CB}$ units per repetition were added for uniaxial compression on texturometer (TA, HD Plus Stable Micro Systems, Surrey, England), with a probe diameter of $100 \mathrm{~mm}$ (P100) and pretest, test, and posttest speed of $5.0 \mathrm{~mm} \mathrm{~s}^{-1}, 2.0 \mathrm{~mm} \mathrm{~s}^{-1,} 2.0 \mathrm{~mm} \mathrm{~s}^{-1}$, respectively. Hardness, fracturability, elasticity, and chewiness were calculated (Pereira et al., 2010).

The results obtained from the physical analyses were compared with those of the frozen commercial CB made using sour cassava starch. The formulation that had similar results to the commercial product was used for the validation of the regression adjusted models and evaluation of the proximal composition, microbiologic risk, and sensorial acceptance.

\section{Proximal composition, microbiological analysis, and sensorial acceptance}

Moisture was determinate of the mass loss from the sample under oven heating at $105^{\circ} \mathrm{C}$ until a constant weight was achieved (method $\mathrm{n}^{\circ} 925.10$ ). The protein content was estimated using the Kjeldahl method for determining total nitrogen, which was converted into crude protein using the factor of 6.25 (method $n^{\circ}$ 960.52). The Soxhlet method was used to extract fat with petroleum ether (method $n^{\circ}$ 945.16). The ash content was determined by carbonization, followed by complete incineration in a muffle furnace at $550{ }^{\circ} \mathrm{C}$ (method $\mathrm{n}^{\circ} 923.03$ ). The total dietary fiber was obtained using the enzymatic-gravimetric method (method $\mathrm{n}^{\mathrm{o}}$ 985.29). The total carbohydrates content was estimated from the difference. All methods were used according to according to AOAC methods (AOAC, 2012).

The presence of coliforms at $45{ }^{\circ} \mathrm{C} \mathrm{g}^{-1}$ and Salmonella spp. were studied as per the Brazilian legislation in force (Brazil, 2001), and to evaluate the hygienic conditions of handling and storage, presence of
Bacillus cereus, coagulase-positive Staphylococci, molds, and yeasts were evaluated using the American Public Health Association (Apha, 2015) methods.

A total of 100 untrained adults (aged 18-65 years, without any obligation to eat the product) evaluated color, flavor, taste, and texture using a nine-point hedonic scale, ranging from 1 (dislike it very much) to 9 (liked it very much). Moreover, the willingness to buy the product was evaluated (Dutcosky, 2013). The global acceptance index was calculated by dividing the mean score by the maximal score obtained (Bastos; Paulo; Chiaradia, 2014). This study was approved by the Federal University of Goiás Ethics Committee $\left(\mathrm{n}^{\mathrm{o}}\right.$ 1616234).

\section{Data analyses}

For physical analyses, the difference between mean values was analyzed using one-way analyses of variance and compared using Tukey's test $(\mathrm{p} \leq 0.05)$ using the software Statistica ${ }^{\circledR}$ for Windows 11.0 (Statsoft Inc., Tulsa, USA).

\section{RESULTS AND DISCUSSION}

\section{Physical characteristics}

Expansion capacity varies with dough aeration degree and size of cells inside bread (Itthivadhanapong; Sangnark, 2016; Zhou; Faubion; Walker, 2011). In this study, the expansion index increased with increasing SWMS replacement. Moreover, CB5 (1.55) and CB1 (1.45) differed statistically, suggesting that only total replacement changed this characteristic. All formulations showed higher values than the commercial product (1.31) (Table 2).

The specific volume also increased from 3.67 to $4.20 \mathrm{~mL} \mathrm{~g}^{-1}$, whereas the commercial product had a lower value $\left(1.88 \mathrm{~mL} \mathrm{~g}^{-1}\right)$. Fermentation followed by $\mathrm{SD}$, greatly altered the expansion characteristics of WMS during baking similar to sour cassava starch. This expansion was because of the oxidation reaction induced by UV sunlight on the fermented starch (Santos; Sartori; Cabello, 2012; Konak; Certel; Karakaş, 2017; Teixeira et al., 2019).

The color of bakery products can be used as a quality parameter. As for other foods, it is the first qualitative parameter evaluated by consumers (Mesomo et al., 2010). In this study, lightness $\left(\mathrm{L}^{*}\right)$, saturation $\left(\mathrm{C}^{*}\right)$, and hue $\left(\mathrm{H}^{\circ}\right)$ were not affected $(\mathrm{p} \leq 0.05)$ by SWMS replacement (Table 2), suggesting that fermentation does not change WMS color in the CB formulations studied. The commercial product was dark red in color and the experimental CB was light yellow in color (Figure 1). 
Table 2: Expansion Index (El), Specific volume (SV), lightness ( $\left.L^{*}\right)$, redness $\left(a^{*}\right)$, yellowness $\left(b^{*}\right)$, Chroma (C), Hue $\left(\mathrm{H}^{\circ}\right)$, and textural parameters (hardness, fracturability, elasticity and chewiness) for Brazilian cheese bread rolls (CB) with different replacement levels of sour waxy maize starch (SWMS) and waxy maize starch(WMS), and a commercial product.

\begin{tabular}{|c|c|c|c|c|c|c|}
\hline \multirow[b]{2}{*}{ Parameter } & \multicolumn{6}{|c|}{ SWMS and WMS replacement levels (\%) ${ }^{1}$} \\
\hline & 100 (CB1) & 75 (CB2) & 50 (CB3) & 25 (CB4) & 0 (CB5) & $\begin{array}{c}\text { Commercial } \\
\text { product }\end{array}$ \\
\hline $\mathrm{El}$ & $1.55^{\mathrm{A}} \pm 0.04$ & $1.50^{\mathrm{AB}} \pm 0.02$ & $1.49^{\mathrm{AB}} \pm 0.05$ & $1.49^{\mathrm{AB}} \pm 0.02$ & $1.45^{\mathrm{B}} \pm 0.02$ & $1.31 \pm 0.05$ \\
\hline $\mathrm{SV}^{2}$ & $4.20^{A} \pm 0.10$ & $4.12^{\mathrm{AB}} \pm 0.11$ & $3.83^{\mathrm{BC}} \pm 0.24$ & $3.68^{c} \pm 0.13$ & $3.67 \pm \pm 0.13$ & $1.88 \pm 0.05$ \\
\hline$L^{*}$ & $79.47^{A} \pm 3.67$ & $79.78^{A} \pm 0.91$ & $83.81^{A} \pm 3.32$ & $84.67^{A} \pm 1.46$ & $84.78^{A} \pm 2.96$ & $71.70 \pm 1.04$ \\
\hline$a^{*}$ & $4.40^{A} \pm 0.35$ & $4.30^{A} \pm 0.35$ & $2.48^{\mathrm{B}} \pm 0.34$ & $2.32^{\mathrm{B}} \pm 0.26$ & $1.98^{\mathrm{B}} \pm 0.27$ & $7.66 \pm 0.83$ \\
\hline$b^{*}$ & $19.42^{\mathrm{A}} \pm 1.44$ & $18.42^{\mathrm{A}} \pm 1.61$ & $17.82^{\mathrm{A}} \pm 0.96$ & $18.03^{\mathrm{A}} \pm 1.05$ & $17.98^{\mathrm{A}} \pm 0.62$ & $24.86 \pm 0.8$ \\
\hline$C^{*}$ & $22.49^{A} \pm 1.54$ & $22.20^{\mathrm{A}} \pm 1.84$ & $20.22^{\mathrm{A}} \pm 1.46$ & $19.90^{A} \pm 0.03$ & $19.86^{\mathrm{A}} \pm 1.04$ & $30.06 \pm 1.53$ \\
\hline $\mathrm{Hue}^{\circ}$ & $78.68^{A} \pm 2.30$ & $77.51^{\mathrm{A}} \pm 2.52$ & $76.95^{\mathrm{A}} \pm 1.52$ & $76.91^{A} \pm 2.29$ & $74.13^{A} \pm 5.19$ & $72.9 \pm 1.19$ \\
\hline Hardness $^{3}$ & $1320.62^{D} \pm 11.60$ & $1406.29^{c} \pm 12.54$ & $1847.88^{\mathrm{B}} \pm 21.43$ & $1855.14^{\mathrm{B}} \pm 17.82$ & $2654.86^{\mathrm{A}} \pm 28.14$ & $991.99 \pm 6.44$ \\
\hline Fracturability $^{3}$ & $1426.34{ }^{\complement} \pm 19.87$ & $1433.52^{c} \pm 19.07$ & $1528.76^{\mathrm{B}} \pm 7.49$ & $1557.85^{\mathrm{B}} \pm 23.39$ & $1778.29^{A} \pm 19.09$ & $0.00 \pm 0.00$ \\
\hline Elasticity $^{3}$ & $0.69^{A} \pm 0.03$ & $0.69^{A} \pm 0.02$ & $0.70^{A} \pm 0.02$ & $0.71^{A} \pm 0.03$ & $0.71^{A} \pm 0.03$ & $0.84 \pm 0.03$ \\
\hline Chewiness $^{3}$ & $381.399^{c} \pm 10.51$ & $387.71^{c} \pm 4.36$ & $456.14^{\mathrm{B}} \pm 34.09$ & $459.94^{\mathrm{AB}} \pm 9.8$ & $515.99^{A} \pm 13.11$ & $416.11 \pm 1.95$ \\
\hline
\end{tabular}

${ }^{1}$ Average values, followed by standard deviation, different superscripts in a row differed significantly $(p \leq 0.05) ;{ }^{2} \mathrm{~mL} \mathrm{~g}{ }^{-1} ;{ }^{3} \mathrm{Newton}$.

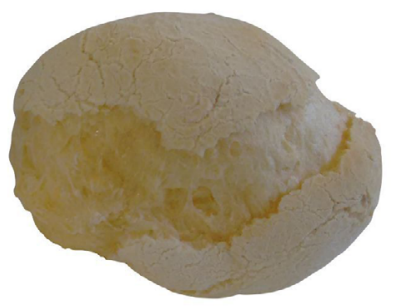

A

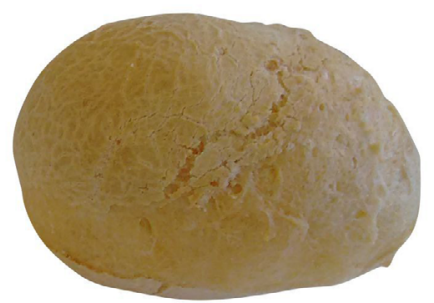

D

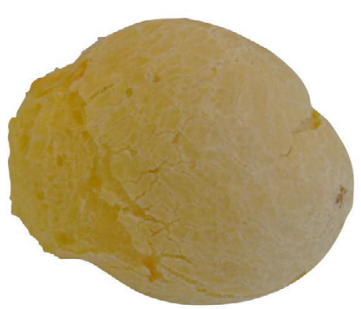

B

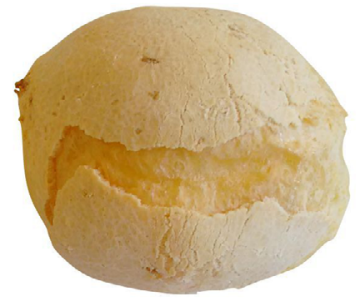

E

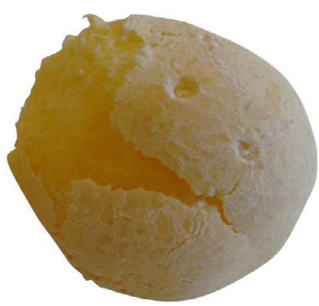

$\mathrm{C}$

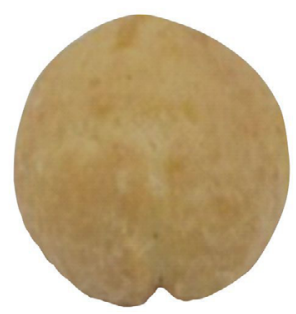

$\mathrm{F}$

Figure 1: Photographs of Brazilians cheese bread rolls produced using different percentages of native waxy maize starch (WMS)/sour WMS replacement: (A) CB1:100/0; (B) CB2:75/25; (C) CB3:50/50; (D) CB4:25/75; (E) CB5:0/100; (F) Commercial product.

This behavior could be explained by the differences in ingredients in the commercial formulations (Eduardo; Svanberg; Ahrné, 2016) and also because maize starch had more lightness than cassava starch when used in CB, according to our results (Table 2, commercial product versus CB). Chroma values are associated with food freshness that has the largest consumer preferences (Lee et al., 2013). For bakery foods, consumers associated 
chroma, less intensity, or pale color with great purity and better hygienic conditions during the process. Pereira et al. (2010) found $\mathrm{L}^{*}, \mathrm{a}^{*}, \mathrm{~b}^{*}$, chroma, and hue values to be approximately $77.83,2.24,26.81,34.83$, and $50.32^{\circ}$, respectively, in $\mathrm{CB}$ with cassava starch. In this study, $\mathrm{L}^{*}$ and $\mathrm{H}^{\circ}$ were higher (more clarity and yellowness) and $\mathrm{C}^{*}$ was lower (less intensity) than the referred studies.

López-Tenorio, Rodríguez-Sandoval and Sepúlveda-Valencia (2015) studied the influence of emulsifier on pandebono, a cheese bread from Colombia made with $50 \%$ sour cassava starch and $20 \%$ maize flour. They observed lower values of $\mathrm{L}^{*}$ (71.59); higher of $\mathrm{a}^{*}$ (8.57), b* (33.58), and chroma (34.40); and similar $\mathrm{H}^{\circ}$ values (77.51) than $\mathrm{CB}$ with SWMS and WMS; however, these values were near to that of the commercial product evaluated.

Hardness, fracturability, and chewiness of CB decreased with the increasing replacement of WMS by SWMS, whereas elasticity remained constant, and all textural properties were higher to experimental CB than the commercial product (Table 2). The alveolar CB structure was formed by dough expansion and water evaporation during baking (Brito; Cereda, 2015).

The increase in the expansion and specific volume of the Brazilians CB rolls produced with a larger proportion of SWMS led to a high percentage of alveolus during baking and lower values of hardness, fracturability, and chewiness. This is because of the action of acids and enzymes in microorganisms, which were catalyzed by UV light during SD, thus changing the starch structure (Putri; Marseno; Cahyanto, 2012; Marcon et al., 2009).

The ability to return to an initial state after deformation (elasticity) did not differ $(\mathrm{p} \leq 0.05)$ ranging from 0.71 to 0.69 for experimental $\mathrm{CB}$ and 0.84 for the commercial product, which could be associated with cassava starch and the cheese type used (Banville et al., 2015; Foegeding et al., 2015; Pereira et al., 2010). CB with $100 \%$ of SWMS showed better physical characteristics than the commercial product (Table 2). Therefore, it was chosen for microbiological, sensory, and physicochemical evaluations; all formulations were suitable.

\section{Proximal composition, microbiological analyses, and sensory acceptance of CB with $100 \%$ of SWMS}

\section{Proximal composition}

According to the Brazilian Food Database (TACO), the proximal composition of baked $\mathrm{CB}\left(\mathrm{g} 100 \mathrm{~g}^{-1}\right)$ was as follows: moisture: 33.7 , crude protein: 5.1 , crude lipids: 24.6, total carbohydrates: 34.2 , total ash: 2.3 , and total energetic value: $363 \mathrm{Kcal}$ (Unicamp, 2011). In this study, lower values of moisture and total energy and higher values of ash, protein, and carbohydrates were observed (Table 3 ). The difference in the proximal composition values could be associated with the use of SWMS and other ingredients used in formulations.

Table 3: Means and standard deviation to proximal composition and sensory responses of Brazilian cheese bread rolls (CB) with $100 \%$ sour waxy maize starch (SWMS).

\begin{tabular}{|c|c|}
\hline Parameter & Levels \\
\hline Moisture $^{1}$ & $31.27 \pm 0.87$ \\
\hline Crude protein ${ }^{1}$ & $9.07 \pm 0.08$ \\
\hline Crude lipids ${ }^{1}$ & $12.8 \pm 1.2$ \\
\hline Total Ash ${ }^{1}$ & $2.86 \pm 0.04$ \\
\hline Total Fibre ${ }^{1}$ & $0.27 \pm 0.01$ \\
\hline Carbohydrates ${ }^{1}$ & 44 \\
\hline Total energetic value ${ }^{2}$ & 326.4 \\
\hline Appearance $^{3}$ & $7.79 \pm 1.33$ \\
\hline Texture $^{3}$ & $8 \pm 1.47$ \\
\hline Flavour $^{3}$ & $7.95 \pm 1.21$ \\
\hline Odour $^{3}$ & $7.8 \pm 1.1$ \\
\hline Wiliness to pay ${ }^{3}$ & $92.5 \pm 13.4$ \\
\hline Global acceptance index ${ }^{3}$ & 98.56 \\
\hline \multicolumn{2}{|c|}{$\begin{array}{l}\text { 1 g } 100 \mathrm{~g}^{-1} ;{ }^{2} \text { kcal } 100 \mathrm{~g}^{-1} ;{ }^{3} \text { Accessors response (\%). Hedoni } \\
\text { scale: } 1 \text { ) Dislike extremely; 2) Dislike very much; 3) Dislike } \\
\text { moderately; 4) Dislike slightly; 5) Neither like nor dislike; } \\
\text { Like slightly; 7) Like moderately; 8) Like very much; } 9 \text { Like } \\
\text { extremely. }\end{array}$} \\
\hline
\end{tabular}

Lemos et al. (2012) studied CB from the amaranth flour and found moisture, crude protein, crude lipids,

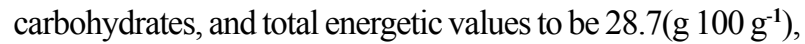

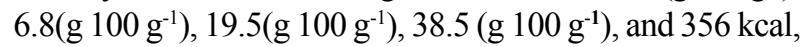
respectively. When these results were compared with our study results, only total energetic value and crude protein were higher, as amaranth flour was used in the $\mathrm{CB}$ formulation. Cavalcante et al. (2016) studied CB using cowpea flour and

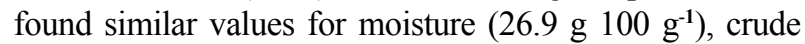

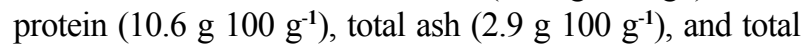
energy ( $321.3 \mathrm{kcal})$.

The characteristics of the final products were compared after the use of a new ingredient (Pereira et al., 2004). However, it is crucial to emphasize that in our study, we did not find a $\mathrm{CB}$ protocol to compare formulations and all formulations used were as per empirical knowledge. 


\section{Microbiologic analyses and sensory acceptance}

$\mathrm{CB}$ was considered safe as no microorganisms were found, and the standard Brazilian legislation in force proposes maximal values only to coliforms at $45^{\circ} \mathrm{C}\left(10^{2}\right.$ Most Probable Number $\mathrm{g}^{-1}$ ) and Salmonella sp. (absence in $25 \mathrm{~g}$ of sample) (Brazil, 2001).

CB with $100 \%$ of SWMS had a score of 7.79 for appearance, 8 for texture, 7.8 for odor, and 7.95 for flavor (Table 3). Other studies on CB showed lower sensory acceptance and willingness to buy as sour cassava starch was increasingly replaced by green banana (Fernandes et al., 2015).

Cavalcante et al. (2016) investigated the replacement of sour cassava starch by cowpea flour and observed low values of willingness to buy (67\%) and global acceptance (72.8\%) when compared with this study. However, $98.56 \%$ of global acceptance index was observed in this study by the assessors, which certainly would buy the product.

\section{CONCLUSIONS}

CB1 formulation had better physical parameters, with $100 \%$ of SWMS and good sensory acceptance. SWMS used in CB rolls showed a higher baking expansion capacity and specific volume than sour cassava starch. The use of SWMS is technologically feasible.

\section{REFERENCES}

AMERICAN PUBLIC HEALTH ASSOCIATION - APHA. Compendium of methods for the microbiological examination of foods, electronic version, Washington, DC. 2015. 998p.

ANJOS, L. D. et al. Modified starches or stabilizers in preparation of cheese bread. Ciência Rural, 44(9):1686-1691. 2014.

BANVILLE, V. et al. Relationship between baked-cheese sensory properties and melted-cheese physical characteristics. Journal of Texture Studies, 46(5):321-334. 2015.

BASTOS, G. A.; PAULO, E. M.; CHIARADIA, A. C. N. Acceptability of potentially probiotic cereal bars. Brazilian journal of food technology, 17(2):113-120.2014.

BERTOLINI, A. C. et al. Photodegradation of cassava and corn starches. Journal of Agricultural and Food Chemistry, 49(2):675-682. 2001.

BRAZIL. Ministry of Health. National Sanitary Surveillance Agency. Resolution RDC ANVISA/MS n. 12, of January 2, 2001. Approved the microbiological standard for food. Official Journal of the Union. Brasília, January 10, 2001.
BRAZIL. Ministry of Health. National Sanitary Surveillance Agency. CNNPA Resolution n. 12, 1978: Special Technical Standards. Official Journal of the Union. Brasília, July 23, 1978.

BRITO, V. H. S.; CEREDA, M. P. Método para determinação de volume específico com o padrão de qualidade do polvilho azedo e sucedâneos. Brazilian Journal of Food Technology, 18(1):14-22. 2015.

CAVALCANTE, R. B. M. et al. Cheese bread enriched with biofortified cowpea flour. Ciência e Agrotecnologia, 40(1):97-103. 2016.

CHADBOURN, K. B. Breads of Brazil. Gluten Free and More, 19(4):49-52, 2016.

DEMIATE, I. M.; KOTOVICZ, V. Cassava starch in the Brazilian food industry. Ciência e Tecnologia de Alimentos, 31(2):388-397, 2011.

DUTCOSKY, S. D. Análise Sensorial de Alimentos. 4. ed. rev. ampli. Curitiba: Champagnat. 2013. 426p.

EDUARDO, M.; SVANBERG, U.; AHRNÉ, L. Effect of hydrocolloids and emulsifiers on the shelf-life of composite cassavamaize-wheat bread after storage. Food Science and Nutrition, 4(4):636-644, 2016.

FERNANDES, D. S. Elaboração de pão de queijo adicionado com farinha de banana verde: Características físicas e sensoriais. Revista Raízes e Amidos Tropicais, 11(1):5665.2015

FOEGEDING, E. A. Transforming structural breakdown into sensory perception of texture. Journal of Texture Studies, 46(3):152-170. 2015.

FOOD AND AGRICULTURE ORGANIZATION OF THE UNITED NATIONS - FAO, FAOSTAT. 2017. Available in: <http://www. fao.org/faostat/en/\#data/QC>. Access in: May, 05, 2017.

INSTITUTO NACIONAL DE METROLOGIA, NORMALIZAÇÃO E QUALIDADE INDUSTRIAL - INMETRO. Informação ao consumidor. Pão de Queijo. 2017. Available in:<http:// www.inmetro.gov.br/consumidor/produtos/paoqueijo. asp>. Access in: October, 20, 2018.

INTERNATIONAL ASSOCIATION OF OFFICIAL ANALYTICAL CHEMISTS- AOAC. Official methods of analysis of the association of official analytical chemists international. AOAC, Gaitherburg, MD. 2012..

ITTHIVADHANAPONG, P.; SANGNARK, A. Effects of substitution of black glutinous rice flour for wheat flour on batter and cake properties. International Food Research Journal, 23(3):1190-1198, 2016. 
KONAK, Ü. I..; CERTEL, M.; KARAKAŞ, B. Effects of ultraviolet irradiation of batter and different baking methods on cake quality. Journal of Microbiology, Biotechnology \& Food Sciences, 7(2):113-117, 2017.

LEE, S. M. et al. Origin of human colour preference for food. Journal of Food Engineering, 119(3):508-515. 2013.

LEMOS, A. R. et al. Effect of incorporation of amaranth on the physical properties and nutritional value of cheese bread. Food Science and Technology, 32(3):427-431. 2012.

LÓPEZ-TENORIO, J. A.; RODRÍGUEZ-SANDOVAL, E.; SEPÚLVEDAVALENCIA, J. U. The influence of different emulsifiers on the physical and textural characteristics of gluten-free cheese bread. Journal of Texture Studies, 46(4):227-239. 2015.

MACHADO, A. V.; PEREIRA, J. Efeito do escaldamento nas propriedades tecnológicas e reológicas da massa e do pão de queijo. Ciência e Tecnologia de Alimentos, 34(2):421427.2010.

MARCON, M. J. A. et al. Expansion properties of sour cassava starch (polvilho azedo): Variables related to its practical application in bakery. Starch Journal, 61(12):716-726. 2009.

MESOMO, M. C. et al. Shelf-life evaluation of cheese bread added of residue from Agaricus blazei Murrill extration. Ambiência, 6(3):427-436. 2010.

PAPALIA, I. S. et al. Development of cheese bread with the addition of guar gum and xanthan gum as a substitute for partial fat. International Food Research Journal, 22(5):2050-2056. 2015.

PEREIRA, J. et al. Função dos ingredientes na consistência da massa e nas características do pão de queijo.
Ciência e Tecnologia de Alimentos, 24(4):494-500, 2004.

PEREIRA, P. A. P. et al. Viabilidade da utilização de queijo tipo ricota na elaboração de pão de queijo. Ciência Rural, 40(11):2356-2360. 2010.

PUTRI, W. D. R.; MARSENO, D. W.; CAHYANTO, M. N. Role of lactic acid bacteria on structural and physicochemical properties of sour cassava starch. APCBEE Procedia, 2:104-109, 2012.

SANTOS, T. P. R.; SARTORI, M. M. P.; CABELLO, C. Relationship between exposure time and concetration of latic acid in the expansion characteristics of modified starch of cassava. Revista Raízes e Amidos Tropicais, 8:27-35, 2012.

SCHIRMER, M. et al. Physicochemical and morphological characterization of different starches with variable amylose/amylopectin ratio. Food Hydrocolloids, 32(1):5263, 2013.

STATSOFT INC. STATISTICA 11.0 for Windows computer program manual (Tulsa, USA). 2011.

TEIXEIRA, C. S. et al. Waxy maize starch modified by sundrying after spontaneous or backslopping fermentation. International Journal of Biological Macromolecule, 135:553-559, 2019.

UNIVERSIDADE ESTADUAL DE CAMPINAS - UNICAMP. Tabela brasileira de composição de alimentos - TACO. 4. ed. revisada e ampliada. Campinas: UNICAMP/NEPA, 2011. $43 p$.

ZHOU, J.; FAUBION, J. M.; WALKER, C. E. Evaluation of different types of fats for use in high-ratio layer cakes. LWT - Food Science and Technology, 44(8):1802-1808, 2011. 